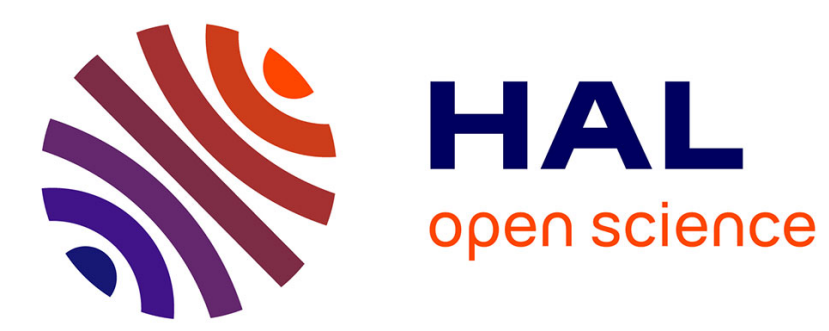

\title{
Life is learning: International EMBS Summer School on Biomedical Imaging [A Look At]
}

Jean-Louis Dillenseger, Valérie Burdin, Christian Roux, Jean-Louis Coatrieux

\section{To cite this version:}

Jean-Louis Dillenseger, Valérie Burdin, Christian Roux, Jean-Louis Coatrieux. Life is learning: International EMBS Summer School on Biomedical Imaging [A Look At]. IEEE pulse, 2012, 3 (1), pp.73. 10.1109/MPUL.2011.2177201 . inserm-00673888

\section{HAL Id: inserm-00673888 https://www.hal.inserm.fr/inserm-00673888}

Submitted on 27 Feb 2012

HAL is a multi-disciplinary open access archive for the deposit and dissemination of scientific research documents, whether they are published or not. The documents may come from teaching and research institutions in France or abroad, or from public or private research centers.
L'archive ouverte pluridisciplinaire $\mathbf{H A L}$, est destinée au dépôt et à la diffusion de documents scientifiques de niveau recherche, publiés ou non, émanant des établissements d'enseignement et de recherche français ou étrangers, des laboratoires publics ou privés. 


\title{
Life is learning: International IEEE EMBS Summer School on Biomedical Imaging
}

\author{
Jean-Louis Dillenseger ${ }^{1,2}$, Valérie Burdin ${ }^{3,4}$, Christian Roux $^{3,4}$, Jean-Louis Coatrieux ${ }^{1,2}$
}

\author{
${ }^{1}$ INSERM U642, Laboratoire Traitement du Signal et de l'Image, 35042 Rennes, France \\ ${ }^{2}$ Université de Rennes I, 35042 Rennes, France \\ ${ }^{3}$ INSERM U650, Brest, France \\ ${ }^{4}$ Institut TELECOM - TELECOM Bretagne, Laboratoire de Traitement de l'Information \\ Médicale, Brest, France
}

Take a small island only reachable by low tide, 45 selected participants, an old manor, world class lecturers, social activities, biomedical imaging, wonderful weather, discussions, discussions and discussions... mix them together and you will get the 10th International IEEE EMBS Summer School on Biomedical Imaging.

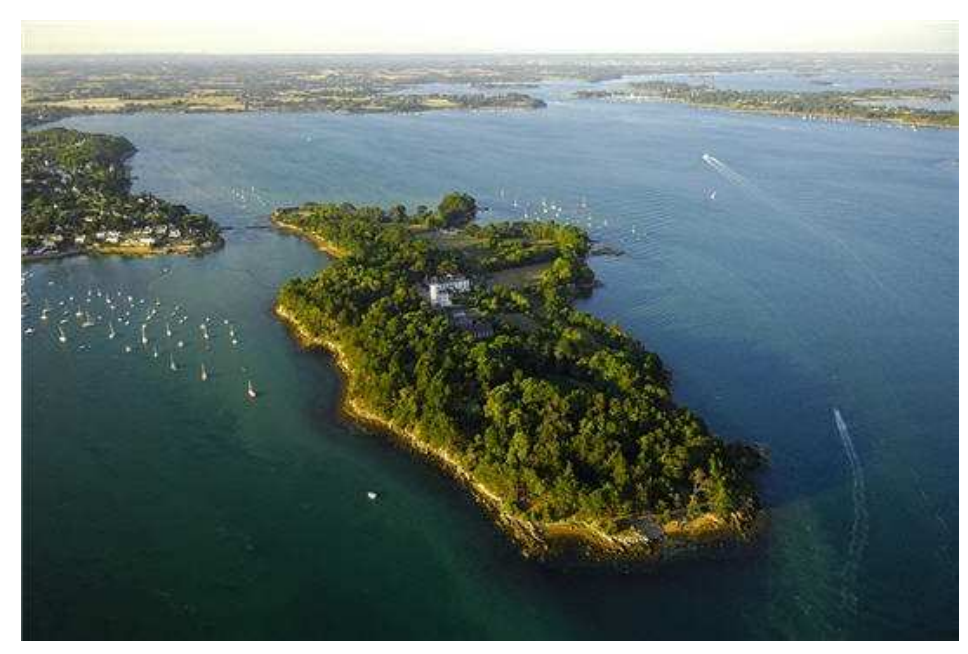

This 10th edition will be held between June 22 to June 30, 2012, on Berder island, Brittany, France. Berder is part of the natural park of the Gulf of Morbihan (i.e "little sea" in britton), recognized as belonging to the 100 most beautiful bays of the world. The Summer School is open to graduate students (M.S., PhD), post doctoral scientists, radiologists, biologists, researchers and engineers from industry.

The program of the lectures will address important topics of the Biomedical Imaging field:

- "Molecular imaging" by Simon Cherry, University of California Davis-USA;

- "Computer-Integrated Surgery" by Russ Taylor, Johns Hopkins University-USA;

- "Biological Image Analysis" by Michael Unser, École Polytechnique Fédérale de Lausanne-Switzerland;

- "Optical Tomography" by Simon Arridge, University College London-UK

- “Nano Robots for Cell Investigation” by Koji Ikuta, University of Tokyo-Japan.

- "Therapeutic Ultrasound" by Jean-Yves Chapelon, INSERM, France.

A call for a Junior lecture is open for all participants to previous Schools.

Lectures, seminars, and discussions are highly interactive and informal with the freedom of spirit that is the tradition of Brittany. The school objective is to contribute without any exclusion to advances in a rapidly evolving field, and to foster participation in the adventure of research. It provides up-to-date, state-of-art knowledge on emerging areas and addresses 
important issues dealing with complex, multivariate systems, going from basic to applied research.

The number of attendees (traditionally coming from more than 25 countries all over the world) is strictly limited (45) and applications must be submitted as early as possible (the formal deadline being February 15th, 2012). An international committee will select the candidates by March 15. Participants are encouraged to present their research work through Posters.

The registration fee is $€ 1000$. It includes accommodation, meals, coffee breaks, visits (Vannes and Carnac alignments) and the School book published in the IEEE-EMBS Book Series. Financial supports are presently requested to the founding partners of the School (Companies, National Institutes) which will allow offering reduced fees mainly for attendees coming from developing countries or countries far from Europe.

Any information can be obtained on the Summer School website: http://ieeess.enst-bretagne.fr or by contacting Valérie Burdin (valerie.burdin@ telecom-bretagne.eu). 